\title{
POTENSI PANAS LAUT SEBAGAI ENERGI BARU TERBARUKAN DI PERAIRAN PAPUA BARAT DENGAN METODE OCEAN THERMAL ENERGY CONVERSION (OTEC)
}

\author{
Erlita Aprilia*, Althaf Aini, Zia Ayu Frakusya, Agus Safril \\ Sekolah Tinggi Meteorologi Klimatologi dan Geofisika \\ ${ }^{*}$ E-mail: erlitaprl@gmail.com
}

\begin{abstract}
ABSTRAK
Energi listrik merupakan suatu hal yang sangat dibutuhkan dalam keberlangsungan kehidupan manusia. Kebutuhan akan energi listrik yang semakin meningkat dari waktu ke waktu memerlukan inovasi baru untuk menghasilkan energi listrik yang ramah lingkungan. Ocean Thermal Energy Conversion (OTEC) adalah metode untuk menghasilkan energi listrik menggunakan prinsip perbedaan temperatur antara laut dalam dan permukaan dengan selisih temperatur minimal sebesar $20^{\circ} \mathrm{C}$ untuk menjalankan mesin kalor. Papua Barat merupakan salah satu provinsi di Indonesia dengan elektrifikasi yang masih rendah. Letak Indonesia yang berada di wilayah tropis dengan perbedaan suhu air laut yang tinggi memiliki potensi untuk memanfaatkan metode OTEC dalam menghasilkan energi listrik. Penelitian ini bertujuan untuk mengetahui potensi pemanfaatan OTEC di perairan sekitar Papua Barat. Data yang digunakan adalah data suhu air laut dalam dan permukaan periode tahun 1955 - 2012 di dua belas titik di perairan sekitar Papua Barat. Data tersebut diperoleh dari World Ocean Atlas 2013 yang kemudian diolah menggunakan perangkat lunak olah data dan Ocean Data View (ODV). Hasil olah data didapatkan nilai efisiensi terbesar yaitu 7,67\% dan terkecil yaitu $7,21 \%$.
\end{abstract}

Kata kunci: energi, suhu air laut, OTEC, nilai efisiensi

\begin{abstract}
Electrical energy is something that is needed in the continuation of human life. The need for electrical energy is increasing from time to time new innovations are purchased to produce environmentally friendly energy. Sea Heat Energy Conversion (OTEC) is a method to produce electrical energy using the temperature difference between the deep sea and the surface with a minimum temperature difference of $20^{\circ} \mathrm{C}$ to run a heat engine. West Papua is one of the provinces in Indonesia with electrification that is still low. The location of Indonesia in the tropics with differences in the temperature of sea water which has great potential to use the OTEC method in producing electricity. This study discusses to study the potential use of OTEC in Papua. The data used are data on the temperature of the deep sea surface and the period of 1955 - 2012 at twelve points in the waters around West Papua. The data was obtained from the World Ocean Atlas 2013 which was then processed using data software and Ocean Data View (ODV). The results of data processing obtained the greatest efficiency value of $7.67 \%$ and excess of $7.21 \%$.
\end{abstract}

Keywords: energy, sea water temperature, OTEC, efficiency value 


\section{PENDAHULUAN}

Papua Barat adalah salah satu provinsi di Indonesia dengan rasio elektrifikasi yang tergolong rendah. Berdasarkan data statitik ketenagalistrikan 2016, nilai rasio elektrifikasi Papua Barat hanya sebesar 47,78\%. Pasokan listrik yang berasal dari PLN saat ini hanya mampu untuk memenuhi kebutuhan rumah tangga, sedangkan untuk kebutuhan industri belum dapat terpenuhi. Seiring dengan meningkatnya pertumbuhan penduduk di wilayah Papua Barat, maka kebutuhan akan listrik pun meningkat. Oleh karena itu, perlu dilakukan pemanfaatan energi terbarukan untuk menunjang kebutuhan energi listrik dimasa sekarang dan dimasa yang akan datang.

Menurut Kishore (2017), energi panas laut merupakan salah satu energi terbarukan ramah lingkungan yang memiliki potensi untuk menghasilkan energi listrik dalam jumlah besar. Saat ini, energi matahari yang diserap laut setara dengan 4000 kali jumlah yang saat ini dikonsumsi manusia. Pada penelitian Hanan (2015), dikatakan bahwa di Indonesia, jenis sumber daya dan potensi energi laut yang diratifikasi versi ASELI (Asosiasi Energi Laut Indonesia) pada tahun 2011; arus pasang surut memiliki potensi teoritis $160 \mathrm{GW}$, potensi teknis $22,5 \mathrm{GW}$, dan potensi praktis $4,8 \mathrm{GW}$; sedangkan untuk gelombang laut memiliki potensi teoritis 510 $\mathrm{GW}$, potensi teknis $2 \mathrm{GW}$, dan potensi praktis 1,2 GW, serta yang terakhir untuk panas laut memiliki potensi teoritis $57 \mathrm{GW}$, potensi teknis $52 \mathrm{GW}$, dan potensi praktis 43 GW. Hasil penelitian Quirapas, dkk (2015) mengestimasikan bahwa potensi energi panas laut Indonesia mencapai $57 \mathrm{GW}$ yang artinya dua kali lipat lebih besar dibandingkan potensi energi panas bumi di Indonesia yang selama ini menjadi salah satu primadona energi baru dan terbarukan. Berdasarkan data tersebut, potensi praktis panas laut memiliki nilai cukup besar yang menandakan adanya potensi yang besar untuk dimanfaatkan dalam menghasilkan energi listrik.

Konversi energi termal laut (Ocean Thermal Energy Conversion/OTEC) merupakan metode untuk menghasilkan energi listrik menggunakan perbedaan temperatur yang berada di antara laut dalam dan perairan dekat permukaan untuk menjalankan mesin kalor. Efisiensi dan energi terbesar mesin kalor dihasilkan oleh perbedaan temperatur yang paling besar. Perbedaan temperatur antara laut dalam dan perairan permukaan umumnya semakin besar jika semakin dekat ke ekuator (Prabowo,2015). Daerah penggunaan metode ini adalah adanya perbedaan tempertatur $20^{\circ} \mathrm{C}$ atau lebih yaitu antara permukaan air laut hingga kedalaman $50 \mathrm{~m}$ dan air pada kedalaman 800 hingga $1.000 \mathrm{~m}$. Suhu air $6^{\circ} \mathrm{C}$ dan $26^{\circ} \mathrm{C}$, secara teori sudah menghasilkan derajat efisiensi kerja 6,7\% (Nugraha, 2012).

Berdasarkan siklusnya, OTEC dibagi menjadi tiga yaitu siklus terbuka, siklus tertutup, dan siklus hybird. OTEC siklus terbuka menggunakan air permukaan hangat yang digunakan secara langsung untuk menghasilkan listrik. Menempatkan air laut hangat ke dalam wadah bertekanan rendah yang menyebabkan air tersebut mendidih. Uap yang dihasilkan kemudian menggerakkan turbin bertekanan rendah yang terpasang pada generator listrik. Uap yang sudah tidak mengandung garam dan kontaminan lainnya dalam wadah bertekanan rendah merupakan air tawar murni. Uap ini kemudian terkondensasi menjadi cairan oleh paparan suhu dingin dari air laut dalam. Metode ini menghasilkan air tawar desalinasi yang cocok untuk air minum dan irigasi. Sistem siklus tertutup menggunakan fluida dengan titik didih rendah, seperti amonia, untuk memberi daya pada turbin untuk menghasilkan listrik. Air laut permukaan yang hangat dipompa melalui penukar panas untuk menguapkan cairan. Uap yang dihasilkan kemudian menggerakan generator turbo. Air laut yang dingin dipompa melalui penukar panas kedua, mengkondensasi uap menjadi cairan, yang kemudian didaur ulang melalui sistem. Sedangkan siklus hybrid menggabungkan fitur dari sistem siklus terbuka dan tertutup. Dalam sistem ini, air laut hangat memasuki ruang vakum dan diuapkan dengan cepat, mirip dengan proses penguapan siklus terbuka (Sakthivel, 2018). 
Provinsi Papua Barat termasuk ke dalam daerah tropis yang cenderung memiliki suhu muka laut yang tinggi dan hampir konstan setiap tahunnya. Perbedaan suhu air laut antara permukaan dan pada kedalaman 1000 meter di wilayah perairan sekitar Papua Barat mencapai kisaran $22^{\circ} \mathrm{C}-24^{\circ} \mathrm{C}$ seperti yang tertera pada gambar 1 . Kondisi seperti ini tentu memiliki potensi yang cukup baik untuk dapat menjalankan metode OTEC untuk menghasilkan energi listrik.

Longitude

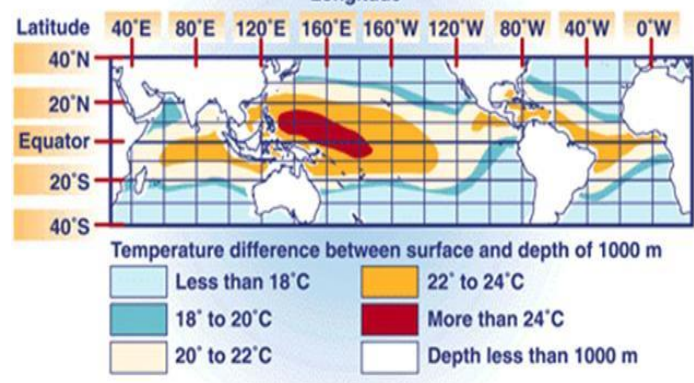

Gambar 1. Peta Perbedaan Suhu Antara Permukaan Laut dan Kedalaman 1000 m (Sumber:http://armand10dma.blogspot.com/2011/ 08/pembangit-listrik-tenaga-panas-laut.html )

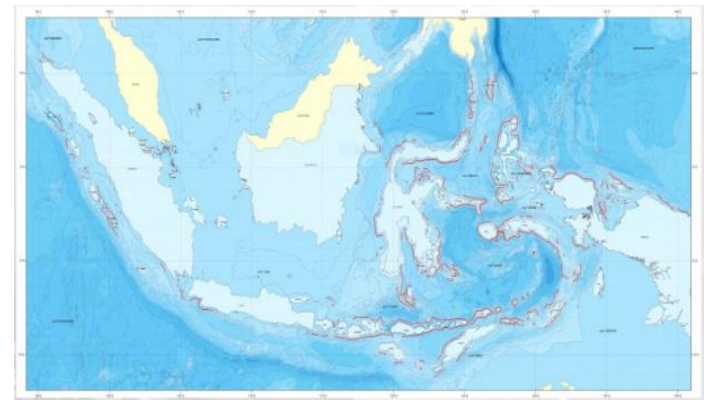

Gambar 2. Atlas Potensi Energi Konversi Termal Laut/OTEC (Puslitbang Geologi Kelautan Asosiasi Energi Laut Indonesia, 2011)

\section{DATA DAN METODE}

Penelitian ini menggunakan data suhu air laut pada permukaan dan pada kedalaman hingga 700 meter yang didapatkan dari WOA (World Ocean Atlas) 2013 periode tahun 1955 - 2012. Data tersebut diunduh dari https://odv.awi.de/data/ocean/world-oceanatlas-2013/. Lokasi yang diteliti yaitu dua belas titik di perairan sekitar Papua Barat dengan koordinat $128^{\circ} \mathrm{BT}-136^{\circ} \mathrm{BT} / 2^{\circ} \mathrm{LU}-$ $6^{\circ} \mathrm{LS}$.

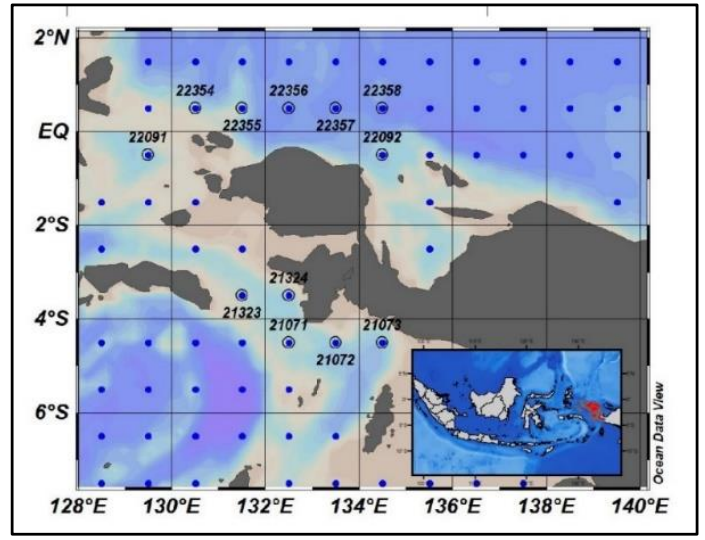

Gambar 3. Peta Lokasi Penelitian (Papua)

Adapun langkah-langkah pengolahan data adalah sebagai berikut :

1. Membuka data dengan perangkat lunak ODV (Ocean Data View).

2. Mengkonversi data kedalam bentuk spreadsheet.

3. Menghitung perbedaan suhu dan nilai efisiensi dengan menggunakan perangkat lunak Microsoft Excel.

Perbedaan suhu dihitung menggunakan rumus sebagai berikut :

$$
\Delta T=T w-T c
$$

Keterangan :

$\Delta T=$ Perbedaan suhu

$T w=$ Suhu air laut permukaan 0 meter.

$T c=$ Suhu air laut kedalaman 700 meter.

Nilai efisiensi dihitung menggunakan rumus sebagai berikut $:^{8}$

$$
\eta=\left(1-\frac{T c}{T w}\right) \times 100 \%
$$

Keterangan :

$\eta=$ nilai efisiensi.

$T w=$ Suhu air laut permukaan 0 meter (dalam Kelvin).

$T c=$ Suhu air laut kedalaman 700 meter (dalam Kelvin).

4. Mendapatkan hasil nilai efisiensi maksimum dan minimum.

5. Menghitung listrik potensial yang dapat dihasilkan dari OTEC. 


\section{HASIL DAN PEMBAHASAN}

\subsection{Analisis Suhu Rata-rata Tahunan Perairan Sekitar Papua Barat}
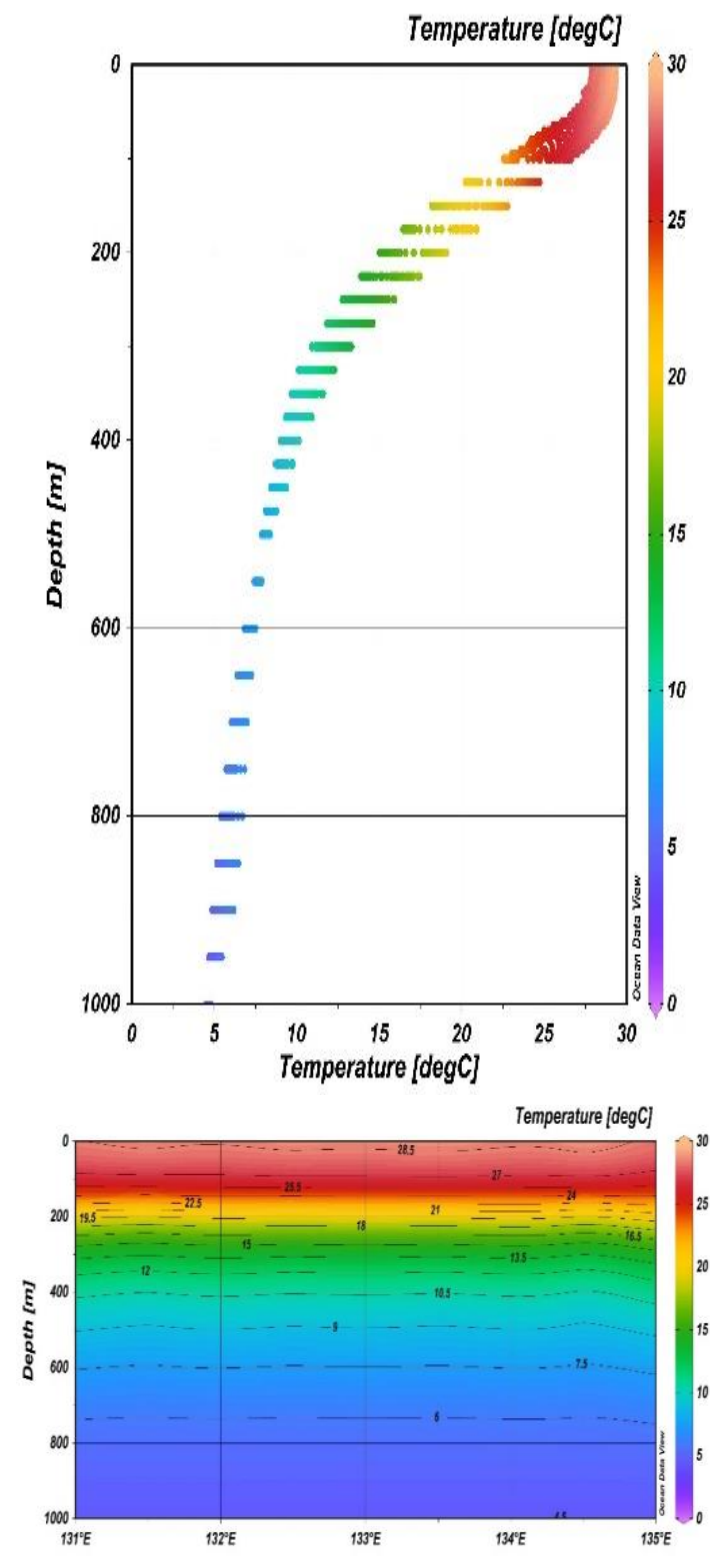

Gambar 4. Profil Suhu Rata-rata Tahunan Berdasarkan Kedalaman

Berdasarkan gambar di atas, dapat diketahui bahwa perairan di sekitar Papua Barat memiliki suhu air laut permukaan yang cukup hangat sebesar $\geq 28,5^{\circ} \mathrm{C}$. Kondisi suhu air laut permukaan yang hangat ini dikarenakan letak wilayah Pulau Papua yang berada di sekitar ekuator sehingga mendapatkan penyinaran Matahari sepanjang tahun dengan intensitas yang tinggi.

Kondisi suhu air laut mengalami penurunan seiring dengan bertambahnya kedalaman laut dan akan kembali stabil pada kedalaman tertentu. Hal tersebut biasa dikenal sebagai lapisan termoklin. Termoklin merupakan bagian dari lapisan perairan laut yang pada lapisan tersebut terjadi penurunan temperatur yang cepat terhadap kedalaman (Nontji, 1993). Nilai absolut gradien penurunan temperatur vertikal pada lapisan termoklin standar adalah sebesar $\pm 0,05^{\circ} \mathrm{C} / \mathrm{m}$. (Bureau of technical supervision of the P.R of China, 1992).

Suhu air laut pada kedalaman 700 meter di wilayah sekitar Papua Barat berkisar pada $6^{\circ} \mathrm{C}$. Dengan demikian, berdasarkan data tersebut dapat diperoleh perbedaan suhu air laut antara permukaan dan pada kedalaman 700 meter berada pada $\geq 22,5^{\circ} \mathrm{C}$.

Salah satu syarat agar dapat menggunakan metode Ocean Thermal Energy Conversion (OTEC) adalah adanya perbedaan antara suhu air laut permukaan dan pada kedalaman tertentu yang mencapai minimal $20^{\circ} \mathrm{C}$. Hal ini menunjukkan bahwa perairan di sekitar Papua Barat sudah memenuhi syarat untuk menggunakan metode OTEC karena didapatkan perbedaan suhu air laut sebesar $\geq$ $22,5^{\circ} \mathrm{C}$

\subsection{Analisis Nilai Efisiensi}

Tabel 1. Hasil Hitung Nilai Efisiensi

\begin{tabular}{|c|c|c|c|c|}
\hline $\begin{array}{c}\text { No. } \\
\text { Titik }\end{array}$ & $\begin{array}{c}\mathrm{Tw} \\
\left({ }^{\circ} \mathrm{C}\right)\end{array}$ & $\begin{array}{c}\mathrm{Tc} \\
\left({ }^{\circ} \mathrm{C}\right)\end{array}$ & $\begin{array}{c}\mathrm{Tw}- \\
\mathrm{Tc}\left({ }^{\circ} \mathrm{C}\right)\end{array}$ & $\begin{array}{c}\text { Efisiensi } \\
(\%)\end{array}$ \\
\hline 21073 & 28.35 & 6.45 & 21.90 & 7.27 \\
21072 & 28.20 & 6.45 & 21.75 & 7.22 \\
21071 & 28.14 & 6.42 & 21.72 & 7.21 \\
21324 & 28.27 & 6.21 & 22.06 & 7.32 \\
21323 & 28.41 & 6.15 & 22.26 & 7.39 \\
22091 & 29.00 & 6.17 & 22.83 & 7.56 \\
22354 & 29.12 & 6.12 & 23.00 & 7.61 \\
22355 & 29.21 & 6.09 & 23.12 & 7.65 \\
22356 & 29.17 & 6.09 & 23.08 & 7.64 \\
22357 & 29.28 & 6.10 & 23.18 & 7.67 \\
22358 & 29.24 & 6.09 & 23.15 & 7.66 \\
22092 & 29.20 & 6.08 & 23.12 & 7.65 \\
\hline
\end{tabular}


Hasil hitung nilai efisiensi di dua belas titik pada wilayah perairan sekitar Papua Barat menunjukkan hasil yang cukup bervariasi. Nilai efisiensi terbesar yang didapatkan bernilai 7,67\%, yaitu pada titik 22357 . Sedangkan nilai efisiensi terkecil yang didapatkan bernilai $7,21 \%$ pada titik 21071 . Jika diasumsikan input daya sebesar $100 \mathrm{KW}$ dengan efisiensi sebesar 7,67\% maka dapat diestimasikan hasil daya bersih yang didapatkan sebesar 7,67 KW.

Selanjutnya, dari tabel tersebut dapat diketahui bahwa terdapat 6 titik yang memiliki nilai efisiensi di atas $7,6 \%$, yaitu titik 22354, 22355, 22356, 22357, 22358, dan 22092. Sedangkan 6 titik lainnya memiliki nilai efisiensi dibawah $7,6 \%$. Titik yang memiliki nilai efisiensi di atas 7,6\% berada di wilayah utara Papua Barat, yaitu di perairan Samudera Pasifik.

Kondisi perairan di wilayah utara Papua Barat yang termasuk ke dalam wilayah Samudera Pasifik ini selain memiliki nilai suhu muka laut yang tinggi, juga memiliki kedalaman laut yang cukup dalam. Hal ini menunjukkan bahwa adanya potensi yang memungkinkan untuk mendapatkan suhu air laut dalam yang lebih dingin dengan kedalaman lebih dari 700 meter. Ketika suhu air laut dalam semakin dingin maka perbedaan suhu air laut yang didapatkan akan semakin tinggi.

Perbedaan suhu air laut permukaan dan suhu air laut di kedalaman yang didapatkan akan berbanding lurus dengan potensi listrik yang dihasilkan. Ketika perbedaan suhu tinggi maka akan menghasilkan nilai efisiensi yang tinggi pula. Semakin efisien suatu mesin bekerja, maka energi yang terbuang akan semakin sedikit. Oleh karena itu, energi listrik yang dihasilkan akan lebih banyak.

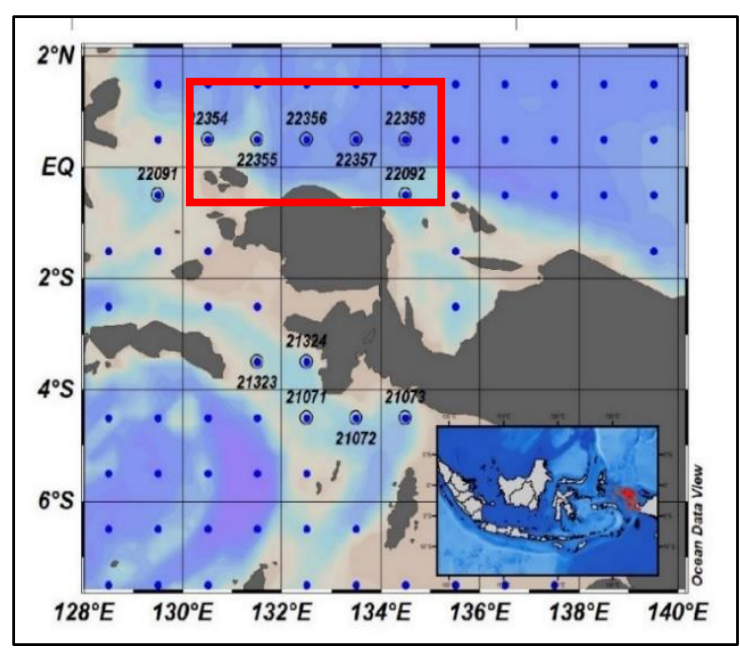

Gambar 5. Peta Lokasi Penelitian (Papua)

\subsection{Analisis Variasi Bulanan di Titik 22357}

Tabel 2. Suhu Air Laut Bulanan Pada Permukaan 0 meter dan Kedalaman 700 meter

\begin{tabular}{|l|c|c|}
\hline \multicolumn{1}{|c|}{ Bulan } & $\mathrm{Tw}\left({ }^{\circ} \mathrm{C}\right)$ & $\mathrm{Tc}\left({ }^{\circ} \mathrm{C}\right)$ \\
\hline Januari & 28.86 & 6.19 \\
Februari & 29.13 & 6.2 \\
Maret & 29.22 & 6.28 \\
April & 29.57 & 6.24 \\
Mei & 29.48 & 6.16 \\
Juni & 29.49 & 6.13 \\
Juli & 29.38 & 5.9 \\
Agustus & 29 & 5.91 \\
September & 29.22 & 5.95 \\
Oktober & 29.2 & 6.13 \\
November & 29.49 & 6.13 \\
Desember & 29.39 & 5.96 \\
\hline
\end{tabular}




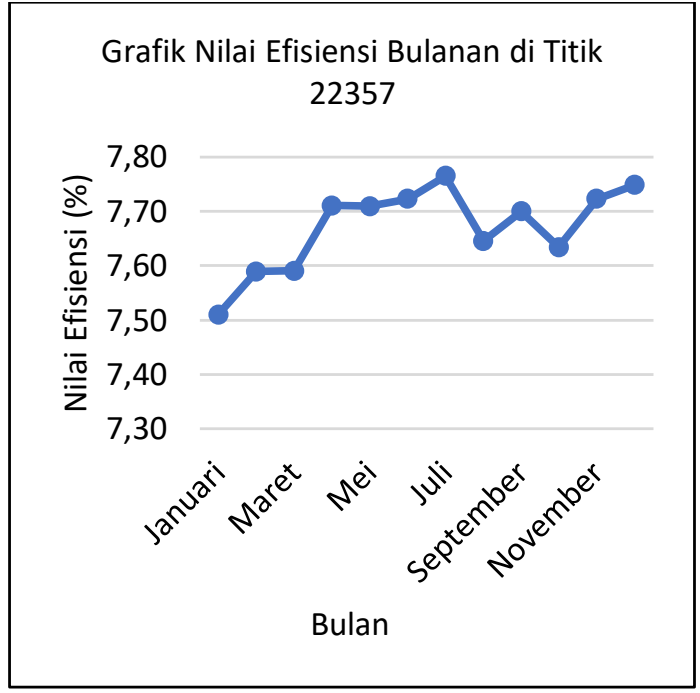

Gambar 6. Grafik Variasi Bulanan di Titik 22357

Tabel 2 menunjukkan nilai suhu air laut pada kedalaman 700 (Tc) dan suhu air laut permukaan (Tw) pada bulan Januari Desember di titik 22357 yang memiliki nilai efisiensi $7,67 \%$. Pada titik ini terlihat bahwa suhu air laut permukaan memiliki kondisi yang cukup hangat dengan rata-rata $29,29^{\circ} \mathrm{C}$. Sedangkan rata-rata suhu air laut di kedalaman 700 meter sebesar $6,10^{\circ} \mathrm{C}$. Perbedaan suhu yang didapatkan mencapai lebih dari $23^{\circ} \mathrm{C}$ dengan efisiensi paling besar pada bulan Juli yang mencapai angka $7,77 \%$.

Jika dilihat berdasarkan gerak semu matahari, yaitu saat bulan Juli posisi matahari berada di belahan bumi utara (BBU) memiliki pengaruh yang cukup signifikan terhadap kondisi suhu air laut di titik 22357 dimana titik ini berada di BBU. Hal ini terlihat bahwa saat bulan Juli suhu air laut permukaan bernilai $29,38^{\circ} \mathrm{C}$ dan suhu air laut dalam bernilai $5,9^{\circ} \mathrm{C}$ sehingga perbedaan suhu yang didapatkan lebih tinggi. Oleh karena itu, nilai efisiensi yang didapatkan pun tinggi seperti yang terlihat dari grafik pada gambar 6 dimana nilai efisiensi pada bulan Juli bernilai $7,77 \%$. Hal ini menunjukkan bahwa potensi energi listrik yang dihasilkan akan lebih besar daripada bulan lainnya dan mencapai kondisi maksimum.

Di sisi lain, pada ketika posisi matahari berada di belahan bumi selatan (BBS) yaitu saat bulan Januari kondisi suhu air laut permukaan tidak sehangat di bulan Juli. Hal ini berpengaruh pada perbedaan suhu dan nilai efisiensi yang dihasilkan menjadi lebih kecil. Sehingga energi listrik yang dihasilkan tidak sebesar dibandingkan bulan lainnya.

Profil suhu air laut berdasarkan kedalaman saat bulan Juli dapat dilihat dari gambar 7 dan saat bulan Januari dapat dilihat dari gambar 8 .

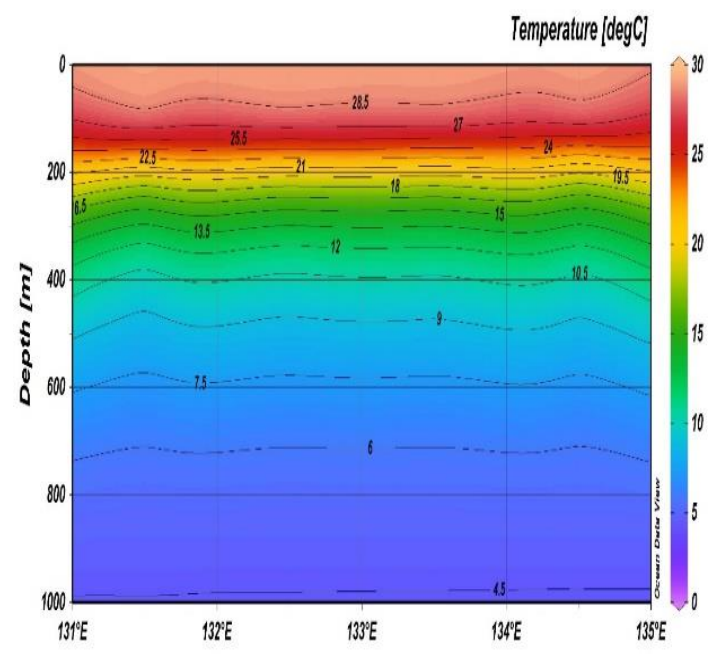

Gambar 7. Profil Suhu Air Laut Berdasarkan Kedalaman di Titik 22357 Saat Bulan Juli

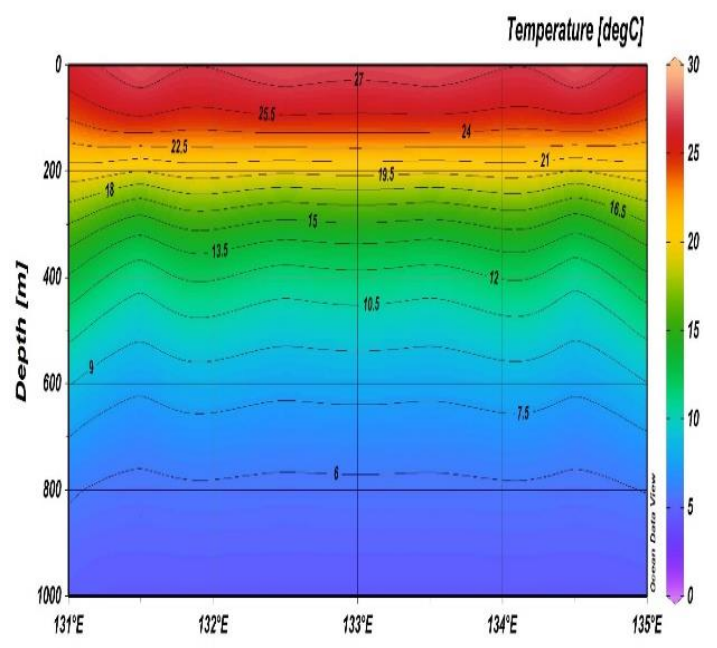

Gambar 8. Profil Suhu Air Laut Berdasarkan Kedalaman di Titik 22357 Saat Bulan Januari 


\subsection{Analisis Listrik Potensial Menggunakan Pembangkit OTEC}

Panjang garis pantai di wilayah utara Papua Barat diasumsikan $350 \mathrm{~km}$ dengan sumber energi OTEC $7,67 \%=26,845 \mathrm{~km}$. Jika diasumsikan jarak antar pembangkit OTEC $100 \mathrm{MW}$ yang dibangun adalah $10 \mathrm{~km}$, maka prakiraan potensi listrik dengan pembangkit listrik OTEC yang dihasilkan sebesar 268,45 MW listrik. Nilai kapasitas faktor OTEC yaitu sebesar 0,8. Dengan demikian, perairan di bagian utara Papua Barat diperkirakan memiliki potensi listrik dengan pembangkit OTEC sekitar $1.881 \mathrm{GWh} /$ tahun. Hasil tersebut yang tertera pada tabel 3 .

Tabel 3. Asumsi Kalkulasi Listrik Potensial OTEC

\begin{tabular}{lll}
\hline No. & Keterangan & Nilai \\
\hline 1 & Sumber OTEC & $26,845 \mathrm{~km}$ \\
& $\begin{array}{l}\text { Prakiraan potensi } \\
\text { listrik }\end{array}$ & $\begin{array}{l}268,45 \mathrm{MW} \\
\text { listrik }\end{array}$ \\
& Efisiensi & $7,67 \%$ \\
& & 700 meter \\
5 & Kedalaman & 1.881 \\
& Listrik Potensial & GWh/tahun \\
\hline
\end{tabular}

\section{KESIMPULAN}

Berdasarkan hasil olah data dan analisis dapat disimpulkan bahwa perairan sekitar Papua Barat memenuhi syarat untuk dapat menggunakan metode OTEC dikarenakan perbedaan suhu air laut pada wilayah tersebut bernilai lebih dari $20^{\circ} \mathrm{C}$. Nilai efisiensi terbesar yang didapatkan bernilai $7,67 \%$ pada titik 22357, sedangkan nilai efisiensi terkecil bernilai 7,21\% pada titik 21071. Di titik 22357, saat bulan Juli didapatkan nilai efisiensi yang terbesar diantara bulan lainnya sehingga potensi listrik yang dihasilkan pada bulan Juli lebih besar. Listrik potensial dari OTEC yang dihasilkan di wilayah utara Papua Barat diestimasikan sebesar 1.881 $\mathrm{GWh} / \mathrm{tahun}$. Namun, hal ini masih diperlukan penelitian lebih lanjut dengan mempertimbangkan langsung kondisi lingkungan disekitarnya dan biaya yang diperlukan untuk menggunakan teknologi OTEC ini.

\section{DAFTAR PUSTAKA}

Andrawina, Y. O., dkk., 2016, Initial Study Of Potency Thermal Energy Using OTEC (Ocean Thermal Energy Conversion) As A Renewable Energy For Halmahera Indonesia, Earth and Environmental Science, IOP Conference Series. doi:10.1088/1755-1315/55/1/012032

Direktorat Jenderal Ketenagalistrikan Kementrian Energi dan Sumber Daya Mineral, 2016, Statistik Ketenagalistrikan 2016, Kementrian Energi dan Sumber Daya Mineral, Jakarta.

Engels, W., dan Zabihian, F., 2014, Principle and Preliminary Calculation of Ocean Thermal Energy Conversion, ASEE 2014 Zone I Conference, University of Bridgeport, Bridgpeort.

Hanan, A., 2015, Pemetaan Potensi Ocean Thermal Energy Conversion (OTEC) di Indonesia, ResearchGate.

Kishore, A., dan Ahmad, A. U., 2017, How to Minimise the Cost of Ocean Thermal Energy Conversion (OTEC), International Journal of Trend in Scientific Research and Development (IJTSRD), 412 - 416.

Koto, J., 2017, Potential of $100 \mathrm{~kW}$ Ocean Thermal Energy Conversion in Indonesia, Prosiding Asosiasi Konferensi Kapal Jepang dan Teknik Kelautan, 763-768.

Meegahapola, L., Udawatta, L., dan Witharana, S., 2007, The Ocean Thermal Energy Conversion Strategies and Analysis of Current Challenges, Second International Conference on Industrial and Information Systems, 8- 11, ICIIS, Sri Lanka.

Nihous, G. C., 2007, A Preliminary Assessment of Ocean Thermal Energy Conversion Resources. Journal of Energy Resources Technology, 10 - 17.

Nugraha, T. dan Didik Sunardi., 2012, Seri Sains Energi Terbarukan : Energi 
Laut,. PT. Pelangi Ilmu Nusantara, 57.

Prabowo, H. 2012. Atlas Potensi Energi Laut. $M \& E$, Vol. 10, no. 4, pp 65 -72.

Quirapas, Mary Ann Joy, dkk., 2015, “Ocean Renewable Energy in Southeast Asia: A Review." Renewable and Sustainable Energy Reviews, 799817.

Ramadhan, A., 2011, Pembangkit Listrik Tenaga Panas Laut, http://armand10dma.blogspot.com/2 011/08/pembangit-listrik-tenagapanas-laut.html, diakses pada 13 Maret 2019.

Sakthivel, C., dkk., 2018, A Review of Ocean Thermal Energy Conversion, Global Research and Development Journal for Engineering, 275 - 281.

Siahaya, Y., dan Salam, L., 2010, Ocean Thermal Energy Conversion (OTEC) Power Plant and It's by Products Yield for Small Islands in Indonesia Sea Water. ICCHT-5th International Conference on Cooling and Heating Technologies, Bandung.

Sidabutar, Herni Cahayani, dkk., 2014, Kajian Lapisan Termoklin Di Perairan Utara Jayapura, Jurnal Oseanografi, 3, 2, 135-141.

Sinuhaji, A. R. 2015, Potential Ocean Thermal Energy Conversion (OTEC) in Bali, KnE Energy , 5-12. 